\title{
Embryotoxic Effects of Polychlorinated Biphenyls (Kanechlors 300 and 500) in Rats
}

\author{
By \\ Kohei Shiota* \\ Department of Anatomy, Faculty of Medicine, Kyoto University \\ (Director: Prof. Hideo Nishimura) \\ -Received for Publication, January 5, 1976-
}

\section{Introduction}

Polychlorinated biphenyls (PCBs) have been used extensively for diverse industrial purposes during the past 40 years, and they are now among the most widely distributed synthetic pollutants in the environment. After the Swedish investigator Jensen (1966) identified PCB residues in fish, birds and mammals from widely dispersed locations, attention has been concentrated on their accumulation in living system and on their possible hazardous effects on animals including man.

In 1968, the public health significance of the PCB pollution became acutely apparent in Japan when approximately 1,000 persons consumed rice oil that had been contaminated with PCBs (Kuratsune et al., 1969). In that "Yusho" incident, exposed persons developed nausea, lethargy, subcutaneous edema of the face and chloracne within a short period. These abnormalities have persisted in many of the affected persons for several years (Kuratsune et al., 1972). The infants born of exposed mothers were smaller than normal, and had brownish discolored skin, abnormal eye discharge and some other symptoms of Yusho (Taki et al., 1969).

Since then, extensive studies have been conducted on a variety of biological effects of PCBs (reviewed by Ad Hoc Committee on Environmental Health Kesearch, 1972, and Fishbein, 1974). As for the embryotoxic or teratogenic action of PCBs, there are several experimental data available. Aroclor $1254(100 \mathrm{mg} / \mathrm{kg} /$ day $)$ given to pregnant rats during pregnancy produced no effect on the viability or morphology of the fetuses (Villeneuve et al., 1971). Daily oral doses of 10 and $30 \mathrm{mg} / \mathrm{kg}$ of Aroclor 1242,1254 and 1260 to pregnant rats on days 6 through 15 of gestation

* Present Address : Department of Human Genetics, National Institute of Genetics, Mishima 411, Japan. 
had no observed effect on the pups (Keplinger et al., 1971). Nishizumi et al. (1969) reported ambiguous embryotoxicity of PCBs in mice but failed to induce congenital malformations. However, incidence of cleft palate significantly increased in offspring from female mice treated with subcutaneous injection of $5 \mathrm{mg} /$ day Kanechlor 500 on days 6 through 15 of gestation (Sugahara et al., 1972). Aroclor 1254 was found to be fetotoxic to the rabbit at daily oral doses of $12.5-50 \mathrm{mg} / \mathrm{kg}$ for the first 28 days of gestation as evidenced by abortions, maternal deaths, and stillborns (Villeneuve et al., 1971). PCB-induced congenital defects and reproductive failures in birds have also been reported by many investigators (McLaughlin et al., 1963, Holmes et al., 1967, Prestt et al., 1970, Pichirallo, 1971, Scott et al., 1971, Dahlgren et al., 1972, Carlson and Duby, 1973, Tumasonis et al., 1973).

The purpose of the present investigation was to clarify what dose levels of PCBs could be hazardous to developing rats and what is the nature of the hazards.

\section{Materials and Methods}

Commercial preparations of PCBs, Kanechlors 300 and 500, manufactured by Kanegafuchi Chemical Industry Co. (Osaka) were obtained from the Japanese Ministry of Health and Welfare. PCBs are represented as "a series of inert, chemically resistent, fire-retarding plasticizers" (Monsanto Co., 1968), and Kanechlors 300 and 500 are oily liquids with an average chlorine content of $41 \%$ and $54 \%$, respectively.

Kanechlors 300 and 500 were individually mixed with the rat basal diet OA-2 (CLEA, Japan, Inc., Takatsuki) at levels of 20, 100 and 500 ppm. The highest level of $500 \mathrm{ppm}$ had been estimated to be near the maximum non-effective dose level for mature female Sprague-Dawley rats on the basis of the subchronic toxicity study for 3 weeks in our laboratory. According to the data given by CLEA, Japan, Inc., the main nutrient components of $100 \mathrm{~g}$ OA-2 were $26.5 \mathrm{~g}$ protein; $3.5 \mathrm{~g}$ fat; $3.5 \mathrm{~g}$ fiber ; $7.5 \mathrm{~g}$ ash ; $1.50 \mathrm{~g}$ calcium; $1.30 \mathrm{~g}$ phosphorus and $1.5 \mathrm{mg}$ thiamine. During the process of preparing the pellets, they were exposed to $120^{\circ} \mathrm{C}$ for ca. 1 second and $80^{\circ} \mathrm{C}$ for 1 hour.

Four-week-old male and female rats of Sprague-Dawley-JCL strain were purchased from CLEA, Japan, Inc., and reared in our laboratory with the basal diet, OA-2, and tap water ad libitum for more than 8 weeks. Each virgin female rat was placed overnight (from 6 p.m. to 9 a.m.) with a male rat of proven fertility. The nonpregnant females and new virgin females were subjected to such mating until the age of 18 weeks. The day on which a vaginal plug was found was taken as day zero of pregnancy. The females with vaginal plugs were randomly divided into 8 groups. Each of the six groups were fed pellets 
containing 20, 100 and $500 \mathrm{ppm}$ of Kanechlor 300 or 500 from day zero until the day of sacrifice. Control groups were fed the basal diet only. Throughout the study, the room tempetature was maintained at $22 \pm 2{ }^{\circ} \mathrm{C}$ and the relative humidity at $55 \pm 5 \%$. The daily light cycle was $12 \mathrm{hrs}$ light, starting at 7:00 a.m., and $12 \mathrm{hrs}$ dark. During pregnancy, the females were weighed daily and inspected for behavioral abnormalities. The amount of food and water consumption was also recorded every day.

On day 21, about three quarters of the pregnant females of each group were sacrificed by cervical dislocation and laporatomized. The numbers of implantations, resorptions and live and dead fetuses were recorded. The live fetuses were removed, dried of amniotic fluid, sexed, and weighed. During this process, they were inspected for gross external and oral malformations. About a half of the fetuses from each litter, randomly selected, were evicerated, fixed in $95 \%$ ethanol, cleared in $1 \% \mathrm{KOH}$ and stained with alizarin red $\mathrm{S}$ by modified Dawson's method. These were examined for skeletal malformations and variations. The remaining fetuses were fixed in Bouin solution for several days, razor-blade sectioned, and examined for internal soft tissus anomalies (Wilson, 1965). In both cases, the fetuses were processed in a manner to equalize the time spent in solution among groups.

The remaining quarter of the pregnant females of each group were allowed to litter naturally, and the postnatal development of the pups was observed. The newborns were examined, weighed, and sexed shortly after birth, and the state of each young, live, dead, or malformed, was recorded. The live pups were branded for identification and allowed to suckle the mother. On the fourth day, the litters were randomly reduced to 8 offspring comprising 4 males and 4 females if possible. If the litter was smaller than 8, pups were fostered from a female of the same treatment group, which had delivered pups on the same day. The pups were weighed weekly thereafter, and inspected for opening of eyelids, unfolding of auricles, opening of vagina, and budding of incisors. When the young were weaned at 3 weeks of age, the dams were killed and the number of implantation sites in the uteri was compared to the number of the newborns counted at the first examination. The weanlings were raised up to 6 week. Then they were sacrificed by ether overdosage and examined for gross external and internal abnormalities.

The data concerning maternal weight and food and water consumption were analyzed using $t$ tests for comparing means. The data relating to fetuses or young were analyzed in the following way in order to minimize biases resulting from the litter effect (Jensh et al., 1970). The percentages or means for a group were computed by first obtaining the percentage or mean for each litter and then calculating 
the average of these percentages or means. The distribution of a percentage or a mean for litters treated with Kanechlors was compared with appropriate control distribution by use of the Wilcoxon rank sum test (Wilcoxon and Wilcox, 1964).

\section{Results}

Effects upon dams.

No marked changes in behavior were observed in the pregnant females during administration of the Kanechlors.

The low and intermediate levels (20 and $100 \mathrm{ppm}$ ) of Kanechlors 300 and 500 had no observed effect on maternal weight gain and food consumption (Table 1). Although the high level $(500 \mathrm{ppm})$ of Kanechlor

Table 1. Weight gain and food consumption of rats given Kanechlors from day 0 to day 21 of gestation

\begin{tabular}{c|c|c|c|c}
\hline \multirow{2}{*}{ Dose } & \multirow{2}{*}{$\begin{array}{c}\text { No. of } \\
\text { pregnant } \\
\text { rats }\end{array}$} & \multicolumn{2}{|c|}{ Average body weight : mean \pm SE $(\mathrm{g})$} & $\begin{array}{c}\text { Average } \\
\text { food intake } \\
\text { (g/day) }\end{array}$ \\
& & Day 0 & Day 21 & \\
\hline Kanechlor 300 & 8 & $272.9 \pm 4.69$ & $375.0 \pm 10.59$ & 19.33 \\
$500 \mathrm{ppm}$ & 11 & $302.2 \pm 4.73$ & $404.4 \pm 8.84$ & 20.81 \\
$100 \mathrm{ppm}$ & 12 & $294.0 \pm 9.14$ & $408.0 \pm 11.23$ & 20.64 \\
$20 \mathrm{ppm}$ & 11 & $292.8 \pm 7.94$ & $418.0 \pm 14.49$ & 20.67 \\
Control & & & & \\
Kanechlor 500 & 12 & $336.9 \pm 10.06$ & $446.3 \pm 13.94$ & 20.90 \\
$500 \mathrm{ppm}$ & 14 & $328.1 \pm 9.11$ & $464.1 \pm 12.95$ & 23.30 \\
$100 \mathrm{ppm}$ & 10 & $345.7 \pm 10.66$ & $501.5 \pm 12.69$ & 23.12 \\
$20 \mathrm{ppm}$ & 7 & $343.1 \pm 10.61$ & $489.1 \pm 12.25$ & 23.01 \\
Control & & & &
\end{tabular}

300 had no significant effect on maternal weight gain and food consumption, the high level of Kanechlor 500 reduced the weight gain of the females during the treatment period, and the difference from the control was significant $(\mathrm{p}<0.05)$ on day 21 of gestation. The consumption of the food containing $500 \mathrm{ppm}$ of Kanechlor 500 was significantly decreased $(\mathrm{p}<0.05)$ on days $1-7,9-11$ and 13 of gestation when compared with the control. The daily intake of the Kanechlors during prenancy calculated from food consumption and body weight was $0.9-1.3 \mathrm{mg} / \mathrm{kg}, 5.3-7.0 \mathrm{mg} / \mathrm{kg}$, and $23.2-37.7 \mathrm{mg} / \mathrm{kg}$ for dose levels of 20,100 and $500 \mathrm{ppm}$, respectively.

Effects upon fetuses.

The effects of Kanechlors 300 and 500 upon rat fetuses observed near term are shown in Tables 2 and 3. 
Table 2. Effects upon rat fetuses of Kanechlor 300 adnimistered orally throughout gestation

\begin{tabular}{|c|c|c|c|c|c|c|c|}
\hline \multirow{2}{*}{ Dose } & \multirow{2}{*}{$\begin{array}{l}\text { No. of } \\
\text { litters }\end{array}$} & \multirow{2}{*}{$\begin{array}{c}\text { No. of } \\
\text { implants } \\
\text { (mean } \pm S E)\end{array}$} & \multirow{2}{*}{$\begin{array}{l}\text { No. of } \\
\text { resorp- } \\
\text { tions } \\
(\%)\end{array}$} & \multicolumn{2}{|c|}{$\begin{array}{l}\text { Weight of fetuses; } \\
\text { mean } \pm S E(g)\end{array}$} & \multirow{2}{*}{$\begin{array}{l}\text { No. of } \\
\text { malformed } \\
\text { fetuses } \\
(\%)\end{array}$} & \multirow{2}{*}{$\begin{array}{c}\text { Type of } \\
\text { malforma- } \\
\text { tion and its } \\
\text { number }\end{array}$} \\
\hline & & & & male & female & & \\
\hline $500 \mathrm{ppm}$ & 8 & $\begin{array}{c}68 \\
(8.5 \pm 0.73)\end{array}$ & $\begin{array}{c}11 \\
(19.2)\end{array}$ & $\begin{array}{r}5.46^{*} \\
\pm 0.054\end{array}$ & $\begin{array}{r}5.07^{*} \\
\pm 0.167\end{array}$ & 0 & \\
\hline $100 \mathrm{ppm}$ & 11 & $\begin{array}{c}97 \\
(8.8 \pm 1.23)\end{array}$ & $\begin{array}{c}23 \\
(20.3)\end{array}$ & $\begin{aligned} & 5.74 \\
\pm & 0.156\end{aligned}$ & $\begin{aligned} & 5.33 \\
\pm & 0.177\end{aligned}$ & $(2.4)$ & $\begin{array}{l}1: \text { club foot, } \\
1: \text { VSD }\end{array}$ \\
\hline $20 \mathrm{ppm}$ & 12 & $\begin{array}{l}116 \\
(9.7 \pm 1.09)\end{array}$ & $\begin{array}{c}16 \\
(14.4)\end{array}$ & $\begin{array}{r}5.40^{*} \\
\pm 0.155\end{array}$ & $\begin{array}{r}5.08 * \\
\pm 0.127\end{array}$ & 0 & - \\
\hline Control & 11 & $\begin{array}{c}112 \\
(10.2 \pm 1.05)\end{array}$ & $\begin{array}{c}18 \\
(19.8)\end{array}$ & $\begin{array}{ll} & 5.91 \\
\pm & 0.083\end{array}$ & $\begin{array}{l}5.46 \\
+0.127\end{array}$ & $(1.0)$ & 1: VSD \\
\hline
\end{tabular}

* Significantly different from control rats : $p<0.05$.

Table 3. Effects upon rat fetuses of Kanechlor 500 administered orally throughout gestation

\begin{tabular}{|c|c|c|c|c|c|c|c|}
\hline \multirow{2}{*}{ Dose } & \multirow{2}{*}{$\begin{array}{c}\text { No. } \\
\text { of } \\
\text { litters }\end{array}$} & \multirow{2}{*}{$\begin{array}{c}\text { No. of } \\
\text { implants } \\
(\text { mean } \pm S E)\end{array}$} & \multirow{2}{*}{$\begin{array}{c}\text { No. of } \\
\text { resorp- } \\
\text { tions } \\
(\%)\end{array}$} & \multicolumn{2}{|c|}{$\begin{array}{l}\text { Weight of fetuses; } \\
\text { mean } \pm \mathrm{SE}(\mathrm{g})\end{array}$} & \multirow{2}{*}{$\begin{array}{l}\text { No. of } \\
\text { malformed } \\
\text { fetuses } \\
(\%)\end{array}$} & \multirow{2}{*}{$\begin{array}{c}\text { Type of } \\
\text { malformation } \\
\text { and its number }\end{array}$} \\
\hline & & & & male & female & & \\
\hline $500 \mathrm{ppm}$ & 12 & $\begin{array}{c}156 \\
(13.0 \pm 0.86)\end{array}$ & $\begin{array}{c}18 \\
(12.8)\end{array}$ & $\begin{array}{r}5.10 * \\
\pm 0.077\end{array}$ & $\begin{array}{r}4.70^{*} \\
\pm 0.057\end{array}$ & $\begin{array}{c}3 \\
(7.0)\end{array}$ & $\begin{array}{l}1: \text { VSD } \\
2: \text { hydronephrosis }\end{array}$ \\
\hline $100 \mathrm{ppm}$ & 14 & $\begin{array}{c}183 \\
(13.1 \pm 0.79)\end{array}$ & $\begin{array}{l}15 \\
(9.4)\end{array}$ & $\begin{array}{l}5.50 \\
\pm 0.102\end{array}$ & $\begin{aligned} & 5.16 \\
\pm & 0.108\end{aligned}$ & $(1.7)$ & $\begin{array}{l}\text { 1: kinked tail } \\
1: \text { VSD }\end{array}$ \\
\hline $20 \mathrm{ppm}$ & 10 & $\begin{array}{c}147 \\
(14.7 \pm 0.42)\end{array}$ & $\begin{array}{c}9 \\
(6.2)\end{array}$ & $\begin{aligned} & 5.56 \\
\pm & 0.091\end{aligned}$ & $\begin{aligned} & 5.22 \\
\pm & 0.081\end{aligned}$ & $\begin{array}{c}1 \\
(0.8)\end{array}$ & $\begin{array}{l}1: \begin{array}{c}\text { protruding } \\
\text { tongue }\end{array} \\
\text { tong }\end{array}$ \\
\hline Control & 7 & $\left(\begin{array}{c}104 \\
(14.9 \pm 0.91)\end{array}\right.$ & $\begin{array}{c}19 \\
(17.6)\end{array}$ & $\begin{aligned} & 5.48 \\
\pm & 0.187\end{aligned}$ & $\begin{aligned} & 5.16 \\
\pm & 0.221\end{aligned}$ & 0 & \\
\hline
\end{tabular}

* Significantly different from control rats : $p<0.05$.

No significant difference was shown in the means of implants and viables fetuses and in the resorption rates between the controls and the Kanechlor-treated groups. It should be noted, however, that the resorption rate was relatively high in the present controls. Suppression of the body weight of live fetuses was observed in the groups administered the Kanechlors, and the difference from the controls was significant $(\mathrm{p}<0.05)$ in the groups given 20 and $500 \mathrm{ppm}$ of Kanechlor 300 and $500 \mathrm{ppm}$ of Kanechlor 500. A dose-effect relationship was apparent in this parameter with the exception of the group given $20 \mathrm{ppm}$ of Kanechlor 300 .

Frequency of malformed fetuses was not significantly different among all groups. As for the types of malformations, several kinds of external and internal anomalies were observed sporadically. The major malformations observed were ventricular septal defect and hydronephrosis. All of the ventricular septal defects were small ones in the membraneous portion. There was no significant increase in 
occurrence of some specific type of anomaly in the treated groups.

The results of examination of the cleared skeletal specimens are shown in Table 4. Incidence of skeletal malformations and variations did not increase in the Kanechlor-treated groups compared with the controls. Retarded ossification was not apparent in any group.

Table 4. Effects upon skeletal development of rat fetuses of Kanechlors administered orally throughout gestation

\begin{tabular}{|c|c|c|c|c|c|}
\hline \multirow[b]{2}{*}{ Dose } & \multirow[b]{2}{*}{$\begin{array}{l}\text { No. of } \\
\text { fetuses }\end{array}$} & \multirow[b]{2}{*}{$\begin{array}{l}\text { No. of ossified } \\
\text { coccygium; } \\
\text { mean } \pm \mathrm{SE}\end{array}$} & \multicolumn{2}{|c|}{ Variations } & \multirow[b]{2}{*}{$\begin{array}{l}\text { other skeletal } \\
\text { anomalies }\end{array}$} \\
\hline & & & $\begin{array}{c}\text { Lumbar } \\
\text { rib } \\
(\%)\end{array}$ & $\begin{array}{c}\text { Deficient } \\
\text { ossification } \\
\text { of sternebrae } \\
(\%)\end{array}$ & \\
\hline \multicolumn{6}{|l|}{ Kanechlor 300} \\
\hline $500 \mathrm{ppm}$ & 28 & $7.5 \pm 0.48$ & 10.8 & 0 & 1: waved rib \\
\hline $100 \mathrm{ppm}$ & 36 & $7.7 \pm 0.41$ & 10.3 & 0 & \\
\hline $20 \mathrm{ppm}$ & 46 & $7.1 \pm 0.20$ & 25.0 & 1.7 & \\
\hline Control & 43 & $8.0 \pm 0.31$ & 35.6 & 1.8 & \\
\hline \multicolumn{6}{|l|}{ Kanechlor 500} \\
\hline $500 \mathrm{ppm}$ & 68 & $7.1 \pm 0.25$ & 5.8 & 14.9 & \\
\hline $100 \mathrm{ppm}$ & 85 & $6.9 \pm 0.25$ & 17.7 & 10.8 & \\
\hline $20 \mathrm{ppm}$ & 69 & $7.1 \pm 0.36$ & 9.4 & 6.2 & \\
\hline Control & 44 & $7.3 \pm 0.14$ & 14.4 & 10.2 & 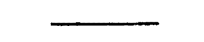 \\
\hline
\end{tabular}

Effects upon postnatal growth.

A summary of the postnatal development of the young is presented in Table 5. Although the mean body weight of the young in the Kanechlortreated groups was less than that of the controls, the differences showed no statistical significance in any age group. There was no significant difference in neonatal death rate and weaning rate among groups.

As a result of autopsy of the young at 6 weeks of age, neither structural defects nor pathological changes of organs were found in any of the groups.

\section{Discussion}

As is known with many other chlorinated hydorocarbon compounds, PCBs tend to accumulate in the food chain, and once ingested by animals, they are degraded or excreted very slowly. The detection of the compound in human diets and tissue (Fishbein, 1974) has raised concern about their possible impact on the health of human beings. There are quite a number of available reports on their biological actions in mature mammals such as liver lesion (Miller, 1944, Vos and 


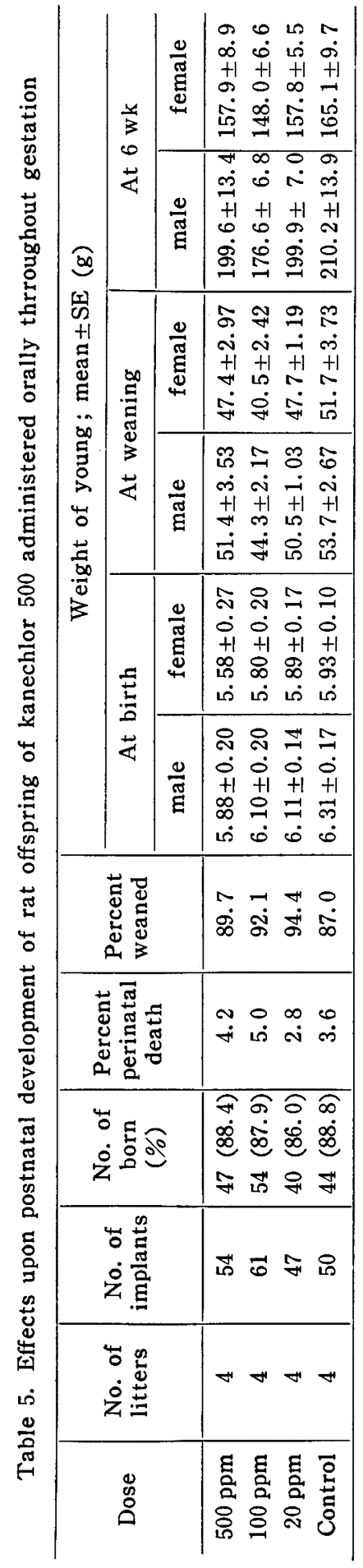

Koeman, 1970, Kimbrough et al., 1972), modification of enzyme activities (Street et al., 1969; Komatsu and Tanaka, 1971; Villeneuve et al., 1971; Benthe et al., 1972; Bickers et al., 1972 ; Litterst et al., 1972; Chen and DuBois, 1973; Johnston et al., 1974 ; Litterst and van Loon, 1974 ; Holub et al., 1975), immunosuppression (Vos and Beems, 1971; Vos, 1972), and carcinogenicity (Kimbrough, in FDA, 1971; Ito et al., 1973). However, adverse effects due to chronic, low-level ingestion of the compound still remain rather poorly known.

In view of a large number of women of child-bearing age and of evidences for the transplacental transfer of PCBs in animals (Curley et al., 1973 ; Kitamura et al., 1973 ; Platonow and Chen, 1973), their possible effects on reproduction should urgently be ascertained. Teratogenicity studies have been conducted using some animal species. As mentioned above, however, the resulrs are somewhat conflicting at present. Reproduction studies of PCBs have also been reported. Monsanto conducted a reproduction study and it was reported by FDA (1970). Aroclors 1242, 1254 and 1260 fed to rats at level of $100 \mathrm{ppm}$ were found to affect reproduction, lowering mating indices, reducing the number of pups delivered and the number of surviving to weaning, and increasing the number of stillborn animals. Keplinger et al., (1971) observed effects on mating performance and/or pup survival in rats fed $100 \mathrm{ppm}$ Aroclor 1242 or 1254 , but found no effect at the same dietary level of Aroclor 1260. In another report, fewer offspring were born after Aroclor 1254 was fed to rats at $100 \mathrm{ppm}$, and the pups born were smaller and had decreased survival time as compared with the control (Kimbrough, 1971). Ringer (1972) showed that feeding of $5 \mathrm{ppm}$ level 
of PCBs completely halted the reproduction of minks. Also, as introduced above, there are increasing number of evidences of reproductive failures caused by PCBs in birds involving chicken.

The results of the present study indicate that oral administration of Kanechlor 300 at $0.9-1.3 \mathrm{mg} / \mathrm{kg} /$ day and Kanechlor 500 at $23-38 \mathrm{mg} /$ $\mathrm{kg} /$ day throughout gestation adversely affects the development of rat fetuse as for the parameter of fetal weight. Administration of Kanechlor 500 at dose levels less than $7 \mathrm{mg} / \mathrm{kg} /$ day exert no notable toxicity on them. The dose-related suppression of the fetal body weight suggests that the observed embryotoxicity is related to administration of the Kanechlors. In evaluating the significance of the embryopathic effects noted in this experiment, consideration must be given to the suppression of food consumption in the rats given $500 \mathrm{ppm}$ of Kanechlor 500 . Since a transient nutritional deficiency during pregnancy may work as a teratogen or enhance effects of other teratogens (Asling, 1969), there is a possibility that the maternal undernutrition was acting in the adverse prenatal effects.

The incidence of malformed fetuses showed no significant difference among all groups, although the types of malformations observed in this experiment did not occur in 4 cases with spontaneous external malformations found among 2,509 fetuses of Sprague-Dawley-JCL rats, according to the observation by Esaki and Tanioka (1970). It can be concluded that oral administration of Kanechlors 300 and 500 at dose level of $38 \mathrm{mg} / \mathrm{kg} /$ day or less is not teratogenic in rats.

It should be noted that the offspring from dams treated with the Kanechlors were smaller than the controls for weeks after birth, although the difference was not statistically significant. In this respect, it is remembered that many of the persons who consumed the PCBcontaining rice oil in the Yusho outbreak continued to experience deleterious effects for several years following ingestion (Kuratsune et al., 1972).

The lowest fetotoxic doses of the Kanechlors for rats in this experiment are estimated to be $1.1 \mathrm{mg} / \mathrm{kg} /$ day for Kanechlor 300 and $28.6 \mathrm{mg} / \mathrm{kg} /$ day for Kanechlor 500 (mean). Little is known concerning the definite effect of degree of chlorination on biological toxicity. For example, the oral toxicity to mature rats decreased with increasing chlorination, while there was no apparent trend of toxicity with chlorination in the data for rabbits (Fishbein, 1974). On the other hand, oral toxicity of PCBs increased with the degree of chlorination in birds (Ad Hoc Committee on Environmental Health Research, 1972).

The observed fetotoxic doses for rats are far higher than the estimated daily intake of PCBs by ordinary Japanese $(0.81-1.48 \mu \mathrm{g} / \mathrm{kg} /$ day, anonymous, 1972). Therefore it can be said that PCBs are not deleterious to human conceptuses so far as the daily intake from natural food chain 
is concerned. But human beings seem to be more sensitive to PCBs' toxicity than rodents, because Yusho babies were born of women who ingested PCBs at the estimated dose level of $65-839 \mu \mathrm{g} / \mathrm{kg} /$ day during pregnancy (calculated from Yamaguchi et al., 1971).

Nishimura et al. (in press) examined the residue levels of PCBs in human embryonic and fetal tissues, and revealed that PCBs do not tend to be concentrated in human fetal tissues. Further investigations are needed to reveal the possible effects of PCBs and other environmental chemicals on human embryos and fetuses.

\begin{abstract}
Commercial preparations of polychlorinated biphenyls (PCBs), Kanechlors 300 and 500, were mixed with food and given to pregnant SpragueDawley rats throughout gestation at levels of 20, 100 and $500 \mathrm{ppm}$. Treatment with $500 \mathrm{ppm}$ of Kanechlor 500 resulted in decreased maternal weight gain and suppressed food consumption. At 20 and $500 \mathrm{ppm}$ of Kanechlor 300 and $500 \mathrm{ppm}$ of Kanechlor 500, the fetal weight decreased significantly. Resorptions and major malformations were not increased by the Kanechlor treatment. These results indicate that PCBs at a high dose level are embryotoxic in the rat, although their teratogenic potential is not evidenced.
\end{abstract}

\title{
Acknowledgement
}

The author is especially grateful to Professor Hideo Nishimura for his guidance and encouragement throughout this study and to Dr. Takashi Tanimura for his valuable advice in undertaking this work.

\section{References}

1) Ad Hoc Committee on Environmental Health Research (Chairman : D. Rall) : PCBsEnvironmental impact. Panel on Hazardous Trace Substances. Environ. Res., 5: 249-362, 1972.

2) Asling, C. W.: Methods for Teratological Studies in Experimental Animals and Man (H. Nishimura and J. R. Miller, eds.), pp. 76-91, Igaku Shoin, Tokyo, 1969.

3) Benthe, H.F., Schumoldt, A. and Schnidt, H.: Induktion mikrosomaler Leberenzyme nach einmaliger Gabe von polychlorierten Biphenylen (PCB) und abschliessender Stress-Situation. Arch. Toxikol., 29: 97-106, 1973 (German).

4) Bickers, D. R., Harber, L.C., Kappas, A. and Alvares, A. P.: Polychlorinated biphenyls: comparative effects of high and low chlorine containing Aroclors on hepatic mixed function oxidase. Res. Commun. Chem. Pathol. Pharmacol., 3: 505-512, 1972.

5) Carlson, R.W. and Duby, R.T.: Embryotoxic effects of three PCBs in the chicken. Bull. Environ. Contam. Toxicol., 9:261-266, 1973.

6) Chen, T.S. and DuBois, K.P.: Studies on the enzyme inducing effect of poly- 
chlorinated biphenyls. Toxicol. Appl. Pharmacol., 26: 504-512, 1973.

7) Curley, A., Burse, V.W. and Grim, M. E.: Polychlorinated biphenyls : Evidence of transplacental passage in the Sherman rat. Food Cosmet. Toxicol., 11: 471$476,1973$.

8) Dahlgren, R. B., Linder, R. L. and Carlson, C. W. : Polychlorinated biphenyls : their effect on penned pheasants. Environ. Health Perspect. 1: 89-101, 1972.

9) Esaki, K. and Tanioka, Y.: The occurrence of spontaneous malformations in ICR-JCL mice and SD-JCL rats. Congenital Anomalies 10: 216-217, 1970 (Japanese).

10) FDA (Food and Drug Administration): Supplement 1. Status report on the chemistry and toxicology of polychlorinated biphenyls (PCB) or Aroclors. December 1970. Unpublished report. 1970.

11) FDA (Food and Drug Administration): Transcript of proceedings of the interagency meeting on polychlorinated biphenyls (PCBs), Aug. 5, 1971. Unpublished data. 1971.

12) Fishbein, L.: Toxicity of polychlorinated biphenyls. Ann. Rev. Pharmacol. 14 : 139-156, 1974.

13) Holmes, D. C., Simmons, J. H. and Tatton, J. O'G.: Chlorinated hydrocarbons in British wildlife. Nature 216: 227-229, 1967.

14) Holub, B. J., Piekarski, J. and Nilsson, K.: The effect of a PCB $\left(2,4,2^{\prime}\right.$, $4^{\prime}$-tetrachlorobiphenyl) on lipid-synthesizing enzymes in rat liver microsomes. Bull. Environ. Contam. Toxicol. 14 : 415-421, 1975.

15) Ito, N., Nagasaki, H., Arai, M., Makiura, S., Sugihara, S. and Hirao, K.: Histopathologic studies on liver tumorigenesis induced in mice by technical poly. chlorinated biphenyls and its promoting effect on liver tumors induced by benzene hexachloride. J. Natl. Cancer Inst. 51: 1637-1646, 1973.

16) Jensen, S. : A new chemical hazard. New Scientist 32:612, 1966.

17) Jensh, R.P., Brent, R. L. and Barr, M., Jr.: The litter effect as a viable in teratologic studies of the albino rat. Am. J. Anat. $128: 185-191,1970$.

18) Johnston, G. J., Ecobichon, D. J. and Hutzinger, O.: The influence of pure polychlorinated biphenyl compounds on hepatic function in the rat. Toxicol. Appl. Pharmacol. 28 : 66-81, 1974.

19) Keplinger, M. L., Fancher, O.-E. and Calandra, J. C.: Toxicologic studies with polychlorinated biphenyls. Presented at the Tenth Annual Meeting, Society of Toxicology, March 7-11, 1971, Washington, D. C., 1971.

20) Kimbrough, R. D.: Presented at the Interagency Meeting on PCBs, U. S. Department of Health, Education, and Welfare, Aug. 5, 1971, Washington, D. C., 1971.

21) Kimbrough, R. D., Linder, R.E. and Gaines, T.B.: Morphological changes in livers of rats fed polychlorinated biphenyls. Arch. Environ. Health 25 : 354-364. 1972.

22) Kitamura, S., Hayakawa, K., Shibata, T. and Hirano, I.: Studies on PCB transfer from mother mouse to fetuses. Jap. J. Hygiene 28: 70, 1973. (Abstract in Japanese).

23) Komatsu, F. and Tanaka, K.: Shortning of hexobarbital sleeping time and change of serum triglyceride level in chlorobiphenyl-sintoxicated rats. Fukuoka Acta Med. 62: 35-41, 1971 (Japanese).

24) Kuratsune, M., Morikawa, Y., Hirohata, T., Nishizumi, M., Kohchi, S., Yoshimụra, T., Matsuzaka, J., Yamaguchi, A., Saruta, N., Ishinishi N., Kunitake, E., Shimono, O., Takigawa, K., Oki, K., Sonoda, M., Ueda, T. and Ogata, M.: An epidemiologic study on "Yusho" or chlorobiphenyls poisoning. Fukuoka Acta Med. 60: 513-532, 1969 (Japanese).

25) Kuratsune, M., Yoshimura, T., Matsuzaka, J. and Yamaguchi, A.: Yusho, a 
poisoning caused by rice oil contaminated with chlorobiphenyls. Environ. Health Perspect. 1: 119- 128, 1972.

26) Litterst, C.L. and van Loon, E. J.: Time-course of induction of microsomal enzymes following treatment with polychlorinated biphenyl. Bull, Environ. Contam. Toxicol. 11: 206-212, 1974.

27) Litterst, C. L, Farber, T. M., Baker, A. M. and van Loon, E. J.: Effect of polychlorinated biphenyls on hepatic microsomal enzymes in the rat. Toxicol. Appl. Pharmacol. 23: 112-122, 1972.

28) McLaughlin, J., Jr., Marliac, G. P., Verrett, M. J., Mutchler, M. K. and Fitzhugh, O.G.: The injection of chemicals into the yolk sac of fertile eggs prior to incubation as toxicity test. Toxicol. Appl. Pharmacol. 5: 760-771, 1963.

29) Miller, J. W.: Pathologic changes in animals exposed to a commercial chlorinated diphenyl. U.S. Publ. Health Rep. 59: 1085-1093. 1944.

30) Monsanto Co.: Aroclor plasticizers. Monsanto Tech. Bull. G/PL-306, 1968.

31) Nishimura, H., Shiota, K., Tanimura, T., Mizutani, T., Matsumoto, M. and Ueda, M. : Levels of polychlorinated biphenyls and organochlorine insecticides in human embryos and fetuses. Pediatrician, in press.

32) Nishizumi, M., Kohchi, S. and Kuratsune, M.: An experimental stuny on "Yusho" or chlorobiphenyls poisoning (preliminary report). Fukoka Acta Med. 60: 539543, 1969 (Japanese).

33) Pichirallo, J.: PCB's : : Leaks of toxic substances raises issue of effects, regulation. Science 173: 899-902, 1971.

34) Platonow, N. and Chen, N. Y.: Transplacental transfer of polychlorinated biphenyls (Arochlor 1254) in a cow. Vet. Rec. 92:69-70, 1973.

35) Prestt, I., Jefferies, D. J. and Moore, N. W.: Polychlorinated biphenyls in wild birds in Britain and their avian toxicity. Environ. Pollut. 1:3-25, 1970.

36) Ringer, R.K.: Cited in: Maugh, T.H., II.: Poyclhlorinated biphenyls : still prevalent, but less of a problem. Science 178: 388, 1972.

37) Scott, M. L., Vadehra, D. V., Mullenhoff, P.A., Rumsey, G. L. and Rice, R.W.: Proceedings of 1971 Cornell Nutrition Conference for Feed Manufacturers. November $2-4,1971$.

38) Street, J. C., Urry, F. M., Wagstaff, D. J. and Blau, A. D.: Comparative effects of polychlorinated biphenyls and organochlorine pesticides in induction of hepatic microsomal enzymes. Presented at 158th Meeting of the American Chemical Society, September 8-12, 1969, New York, 1969.

39) Sugahara, T., Kawakatsu, K. and Watanabe, M.: Experimental induction of cleft palate in mice. Jap. J. Public Health 19(10) Suppl.: 188, 1972 (Japanese).

40) Taki, I., Hisanaga, S. and Amagase, Y.: Report on Yusho (chlorobiphenyls poisoning). Pregnant women and their fetuses. Fukuoka Acta Med. 60:471-474, 1969 (Japanese).

41) Tumasonis, C.F., Bush, B. and Baker, F. D.: PCB levels in egg yolks associated with embryonic mortality and deformity of hatched chicks. Arch. Environ. Contam. Toxicol. 1: 312-324, 1973.

42) Villeneuve, D. C., Grant, D. L., Khera, K., Clegg, D. J., Baer, H. and Phillips, W.E. J.: The fetotoxicity of a polychlorinated biphenyl mixture (Aroclor 1254) in the rabbit and in the rat. Environ. Physiol. 1:67-71, 1971.

43) Vos, J. G.: Toxicity of PCB on non-human mammals and on birds. Environ. Health Perspect. 1: 105-117, 1972.

44) Vos, J. G. and Beems, R. B.: Dermal toxicity studies of technical polychlorinated biphenyls and fractions thereof in rabbits. 19:617-633, 1971.

45) Vos, J.G. and Koeman, J.H.: Comparative toxicological study with polychlorinated biphenyls in chickens with special reference to porphyria, edema 
formation, liver necrosis and tissue residues. Toxicol. Appl. Pharmacol. 17: 656-668, 1970.

46) Wilcoxon, F. and Wilcox, R. A.: Some Rapid Statistical Procedures, pp. 7-9, Lederle Laboratories, Pearl River, New York, 1964.

47) Wilson, J.G.: Teratology: Principles and Techniques (J.G. Wilson and J. Warkany, eds.), pp. 251-277, Univ. of Chicago Press, Chicago, Illinois, 1965.

48) Yamaguchi, A., Yoshimura, T. and Kuratsune, M.: A survey on pregnant women having consumed rice oil contaminated with chlorobiphenyls and their babies. Fukuoka Acta Med. 62: 117-122, 1971 (Japanese).

49) Anonymous.: Allowable residue levels of PCBs. Shoku no Kagaku (Food Sciences) 8: 96-103, 1972 (Japanese). 